\title{
Ege Üniversitesi Hastanesinde görülen melanom dışı deri kanserlerinin epidemiyolojik ve demografik özellikleri
}

\section{Epidemiological and demographic characteristics of non-melanoma skin cancers in Ege University Hospital}
Ayda Acar ${ }^{1}$ (D)
Banu Yaman ${ }^{2}$
Ayris Yanmaz ${ }^{1}$
Işıl Karaarslan 10
Taner Akalın²
Fezal Özdemir ${ }^{1}$ (10)
Ayşe Hande Yoldaş 1 (1)
Ayşe Caner 3
Gülşen Kandiloğlu²
Ayfer Haydaroğlu4
Bengü Gerçeker Türk ${ }^{1}$
${ }^{1}$ Ege Üniversitesi Tıp Fakültesi Deri ve Zührevi Hastalıklar Anabilim Dalı, İzmir, Türkiye
${ }^{2}$ Ege Üniversitesi Tıp Fakültesi Tıbbi Patoloji Anabilim Dalı, İzmir, Türkiye
${ }^{3}$ Ege Üniversitesi Kanserle Savaş Araştırma ve Uygulama Merkezi, İzmir, Türkiye
${ }^{4}$ Ege Üniversitesi Tıp Fakültesi Radyasyon Onkolojisi Anabilim Dalı, İzmir, Türkiye

Öz

Amaç: Bu çalışmada Ege Üniversitesi Hastanesi veri tabanındaki 1992-2017 yılları arası melanom dışı malign deri kanseri tanısı alan hastaların epidemiyolojik ve demografik özelliklerinin değerlendirilmesi amaçlanmıştır.

Gereç ve Yöntem: Ege Üniversitesi Kanserle Savaş Araştırma ve Uygulama Merkezinin özel eğitimli ve sertifikalı kanser kayıt elemanları tarafından CANREG 4 programı ile kaydedilen 1992-2017 yılları arasında Ege Üniversitesinde kayıtı 8395 melanom dışı malign deri kanseri tanıı hastanın; tanı yaşı, cinsiyeti, tümörün histopatolojik tanısı, tümör yerleşim yeri, hastalık evresi ve uygulanan tedavi yöntemleri değerlendirilmiştir. Kategorik değişkenler arası ilişki varlığı Ki-Kare yöntemiyle değerlendirilirken, gruplar arası nümerik değişkenler Kruskal Wallis ve Dunn Testi ile karşılaştırıldı. Tüm Hipotez testleri 0,05 önem seviyesinde uygulandı.

Bulgular: Ege Üniversitesi Kanser Araştırma Merkezinde 1992 ile 2017 yılları arasında kayıtlı melanom dışı deri kanseri olan 8395 hastanın 8386'sı dahil edildi. Hastaların \%55,9'unda bazal hücreli karsinom, \%30,3'ünde skuamoz hücreli karsinom, \%3,6'sında malign kutanöz yumuşak doku tümörü, $\% 3,4$ 'ünde bazoskuamoz karsinom, \%2,7'sinde kutanöz lenfoma, \%1,4'ünde malign deri eki tümörü, $\% 0,4$ 'ünde Merkel hücreli karsinom, \%2,3'ünde sınıflandırılamayan tümör mevcuttu. Hastaların

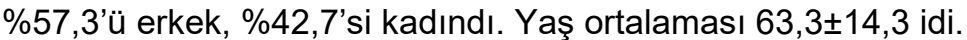

Sonuçlar: Olguların çoğunu epitelyal karsinomlar oluşturmakta idi. Çalışmada en sık görülen kanser tipi bazal hücreli karsinomdu ve bunu ikinci sırada skuamoz hücreli karsinom izlemekteydi. En az görülen Merkel hücreli karsinomdu. Merkel hücreli karsinom dışında erkek cinsiyet daha baskındı. Yaş ortalaması en genç olan grup kutanöz lenfomalarken, en ileri yaş gruplu tümör skuamoz hücreli karsinomdu.

Anahtar Sözcükler: Melanom dışı deri kanserleri, bazal hücreli karsinom, skuamoz hücreli karsinom, bazoskuamoz karsinom, kutanöz lenfoma.

\section{Abstract}

Aim: We aimed to evaluate the epidemiological characteristics of patients diagnosed as nonmelanoma skin cancer in the database of Ege University Hospital between 1992-2017.

Sorumlu yazar: Ayda Acar

Ege Üniversitesi Tıp Fakültesi Deri ve Zührevi Hastalıklar

Anabilim Dalı, İzmir, Türkiye

E-posta: aydaerbas@yahoo.com 
Materials and Methods: The data of 8395 patients diagnosed with non-melanoma skin cancer enrolled at Ege University between 1992-2017, recorded by the CANREG 4 program by specially trained and certified cancer registry staff of the Ege University Cancer Control Research and Application Center, were collected and evaluated in terms of age, sex, histopathological diagnosis of the tumor, tumor location, disease stage and treatment methods. While the existence of the relationship between categorical variables was evaluated with the Chi-Square method, the numerical variables between the groups were compared with the Kruskal Wallis and Dunn Test. All Hypothesis tests were applied at 0.05 significance level.

Results: 8386 of 8395 patients with non-melanoma skin cancer registered between 1992 and 2017 at the Cancer Research Center of Ege University were included. Of 55.9\% patients had basal cell carcinoma, 30.3\% had squamous cell carcinoma, 3.6\% had malignant cutaneous soft tissue tumor , $3.4 \%$ had basosquamous carcinoma, 2.7\% had cutaneous lymphoma, $1.4 \%$ had malignant cutaneous adnexal tumors, $0.4 \%$ had Merkel cell carcinoma and $2.3 \%$ had unclassified tumor. Of $57.3 \%$ patients were male and $42.7 \%$ were female. The average age was $63.3 \pm 14.3$.

Conclusions: In our study most of the cases were epithelial carcinomas. The most common cancer was basal cell carcinoma, followed by squamous cell carcinoma. The least common tumor was the Merkel cell carcinoma. Except Merkel cell carcinoma, the male sex was more dominant. The group with the youngest mean age was cutaneous lymphomas, while the older age group was squamous cell carcinoma.

Keywords: non-melanoma malignant skin cancer, basal cell carcinoma, squamous cell carcinoma, basosquamous carcinoma, cutaneous lymphoma, survival.

\section{Giriş}

Deri kanserleri beyaz ırkta en sık görülen kanser grubudur. Başlıca melanom ve melanom dışı deri kanserleri (MDDK) olarak iki gruba ayrılmaktadır. Melanom dışı deri kanserlerinin görülme sıklığı melanoma göre 20 kat daha fazladır. Melanom dışı deri kanserlerinin yaklaşık olarak \%99'unu bazal hücreli karsinom (BHK) ve skuamoz hücreli karsinom (SHK) oluşturur (1). Amerika'da yılda yaklaşık olarak 3,500,000 MDDK olgusu yeni tanı almaktadır (2).

Keratinosit karsinomları olan SHK ve BHK kadınlara göre erkeklerde daha sık görülür ve yaşla birlikte görülme sıklığı artar. Son yıllarda MDDK vakalarındaki artış, iklim değişikliği ve artmış yaşam süresine bağlanabilir. MDDK insidansları coğrafi bölgelere göre farklılıklar göstermektedir. Vaka sayısındaki çokluğa karşın mortalite oranlarının düşük olması nedeniyle dünya çapında MDDK kayıtlarının tutulmasında eksiklikler olabilmektedir (1).

Kutanöz SHK (kSHK) epidermal keratinositlerden kaynaklanan, tüm deri kanserlerinin yaklaşık olarak \%20'sini oluşturan ve BHK'dan sonra ikinci en sık görülen deri kanseridir $(3,4)$. Kutanöz SHK'ın insidansı 100.000 'de $15-35$ arasındadır ve yıllık olarak \%2-4 oranında artış göstereceği tahmin edilmektedir (2). Kümülatif, uzun süreli güneş ışığı maruziyeti, yapay ışık kaynağı maruziyeti (yapay bronzlaştırıcı ve psoralen +Ultraviyole A (PUVA)), kseroderma pigmentozum, albinizm gibi bazı genetik bozukluklara sahip olmak, immünsupresif ilaç kullanımı veya immünsupresif duruma neden olan hastalıklara sahip olmak, organ nakli yapılmış olması, epidermolizis bülloza gibi kronik yara veya yanık yaralarına sahip olmak, insan papillomavirüsleri, sigara içmek, uzun süreli diskoid lupus lezyonları, eroziv liken planus, liken skleroz gibi deri hastalıklarına sahip olmak kSHK gelişim riskini artıran faktörler arasındadır $(3,4)$.

Kutanöz SHK genellikle ileri yaşta olan kişilerin güneş gören deri bölgelerinde ortaya çıkmaktadır. Kutanöz SHK, prekürsor lezyonları olan aktinik keratoz ve SHK in situ (Bowen hastalığı) üzerinden gelişebileceği gibi de novo olarak da gelişebilmektedir (5).

Kutanöz SHK'da tümör alanında lokal invazyon, lenf nodu metastazı ve uzak metastaz görülebilir (4). Metastaz bölgeleri sıklık sırasına göre kutanöz in transit, rejyonel lenf nodu ve uzak metastaz şeklindedir (6). Metastatik kSHK insidansı \%0,5-16 olarak bildirilmiştir (1). Tedavide ilk seçenek cerrahidir. Düşük riskli ve yüzeyel primer kSHK tedavisinde küretaj ve elektrodesikasyon ile kriyoterapi değerlendirilebilir. Lokalizasyon, boyut veya yaş nedeniyle cerrahi yapılamayan hastalarda, cerrahi sonrası pozitif sınır varlığında, lenf nodu 
tutulumu ve/veya metastaz varlığında radyoterapi (RT) uygulanabilir. Metastatik ileri evre kSHK'da platin türevleri, 5-fluorourasil, bleomisin, metotreksat, adriamisin, taksanlar, gemsitabin, ifosfomid kullanılabilen kemoterapötik ajanlardır (3).

Bazal hücreli karsinom epidermisin bazal tabakasından kaynaklanan ve en sık görülen deri kanseridir (7). Genel olarak yavaş büyür ve nadiren metastaz yaparlar. Ancak lokal invazyon ve çevre dokuda destrüktif seyir gösterebilme özelliğine sahiptir. İnsidansı; mesleki ve ırksal özellikler ile güneş ışınlarına maruz kalma şiddetini değiştiren coğrafi faktörlere bağlı olarak değişir. Avustralya, dünyadaki en yüksek BHK oranına sahiptir ve bazı bölgelerinde yılda \%2'ye kadarlık bir insidans bildirilmiştir (8). Amerika Birleşik Devletleri'nde yıllık oranların; 100.000 beyaz erkek başına 407 ve 100.000 beyaz kadın başına 212 vaka olduğu tahmin edilmektedir (9). Açık ten ve göz rengi ile kızıl saça sahip olmak, Kuzey Avrupa soyundan olmak, ileri yaşta olmak, çocukluktan itibaren çillerin var olması ve sık güneş yanı̆̆ı öyküsü olması; ultraviyole radyasyon (UV) maruziyeti ile ilişkili BHK riskini arttırmaktadır (10). Ayrıca uzun süreli arsenik maruziyeti, diğer deri hastalıkları, iyonlaştırıcı radyasyon tedavisi almış olmak ve immünsupresyon; BHK için ek risk faktörleridir (11-13). Birçok farklı klinik ve histopatolojik alt tipi mevcuttur. Bazal hücreli karsinomun metastazı nadir olup, oranları \%0,0028 ila 0,55 arasında değişmektedir. En sık bölgesel lenf düğümlerine metastaz yapar, bunu kemik ve akciğer izler. Metastatik hastalığın prognozu kötüdür, ortalama sağ kalım (SK) 8 ay ile 3,6 yıl arasında değişmektedir (14). Düşük riskli BHK'un standart tedavisi en az 4 mm'lik sınırla cerrahi eksizyondur (15). Cerrahi kapama öncesi sınır değerlendirilmesi ile birlikte yapılan cerrahi tedaviler nüks riskini azaltmaktadır. Konvansiyonel cerrahi eksizyon dışı diğer tedavi seçenenekleri; mohs mikrocerrahisi, elektrodesikasyon ve küretaj, kriyocerrahi, topikal imikimod, topikal flurourasil, fotodinamik terapi, radyasyon terapisi ve intralezyonel interferon (IFN), flurourasil veya bleomisin enjeksiyonları ve sistemik vismodegib tedavisidir. Tümör bölgesi, patolojik alt tip, hastanın klinik durumu, olası kozmetik sonuca göre tedavi yöntemine karar verilir.

Tüm deri tümörlerinin yaklaşık \%1,2 ila 2,7'sini oluşturan Bazoskuamoz karsinom (BSK) çoğunlukla ileri yaşlı açık tenli kişilerin güneş gören baş ve boyun bölgelerinde yerleşir. Lokal agresif bir tümördür ayrıca metastaz ve rekürrens riski de yüksektir. Bazoskuamoz karsinom histolojik olarak BHK ve SHK'nin her ikisini de içeren ve aralarında BHK ve SHK hücre farklılaşmasının bir ara aşamasından oluşmuş geçiş bölgesi bulunan bir tümör olarak tanımlanır (16). Bazoskuamoz karsinomun BHK mı yoksa SHK mı varyantı olup olmadığı literatürde tartışmalıdır. Bazoskuamoz karsinom hastaları yanlışıkla BHK ve SHK tanıları alabildiğinden BSK tanısının doğru konulabilmesi için alınan biyopsinin yeterli büyüklükte ve çok sayıda olması önerilmektedir (17).

Deri eki tümörleri normal derideki sebase, foliküler, ekrin ve apokrin ünite gibi farklı adneksiyal epitel tiplerinden birine farklılaşma gösteren benign ve malign tümörleri barındıran heterojen bir gruptur. Çoğunluğunu benign tümörler oluşturmaktadır. Burada malign deri eki tümörlerinden bahsedilecektir. Foliküler diferansiyasyon gösteren malign tümörler; pilomatrikal karsinom, prolifere trikilemmal tümör, trikilemmal karsinom ve trikoblastik karsinomdur. Sebase diferansiyasyon gösteren malign tümör sebase karsinomdur. Apokrin ve ekrin diferansiyasyon gösteren malign deri eki tümörleri; adneksiyal adenokarsinom NOS, mikrokistik adneksiyal karsinom, porokarsinom, spiradenom/silindirom/spiradenosilindiromdan köken alan malign neoplaziler, malign mikst tümör, hidradenokarsinom, müsinöz karsinom, endokrin müsin-üreten ter bezi karsinomu, adenoid kistik karsinom, dijital papiller adenokarsinom, apokrin karsinom, skuamoid ekrin duktal karsinom, siringokistadenokarsinoma papilliferum, sekretuar karsinom, kribriform karsinom ve taşlı yüzük hücreli// histiyositoid karsinom olarak sıralanabilir. Bu tümörlerin çoğu oldukça nadir görülmektedir (18). Porokarsinomun lokal rekürrensi $\% 17$, nodal metastaz oranı \%19, uzak metastaz ve ölüm oranı \%11 olarak bildirilmiştir. Sebase karsinomun uzak metastaz oranı \%20-25 olup 5 yıllık hastalıktan ölüm riski \%30'a varabilmektedir (19).

Merkel hücreli karsinom (MHK) nadir görülen fakat çok agresif ve yüksek mortaliteye sahip kutanöz nöroendokrin bir tümördür. Çoğunlukla Merkel hücreli polyomavirüs ile ilişki göstermektedir. Ultraviyole maruziyeti ve immünsupresif durum diğer risk faktörlerini 
oluşturmaktadır. İleri yaşlı bireylerin güneş gören alanlarında asemptomatik, sert, mavi-kırmızı renkli nodüler lezyonlar ile karakterizedir (20-22). Öncelikli tedavi $1-2 \mathrm{~cm}$ sınırla lezyonun geniş eksizyonla çıkarılmasıdır. Klinik ve ultrasonografik olarak bölgesel lenf bezinde tutulum saptanmazsa eksizyonla eş zamanlı sentinel lenf nodu biyopsisi yapılması önerilir. Radyoterapi, cerrahi yapılamayan hastalara ya da adjuvan olarak cerrahi sonrası primer tümör ve bölgesel lenf nodu alanına uygulanabilir (22). Metastatik hastalıkta etopozid, taksanlar ve antrasiklinler gibi kemoterapi ajanları ile programlanmış hücre ölüm protein-1 (PD-1) ve programlanmış hücre ölüm ligandı 1 'i (PDL-1) hedefleyen avelumab, pembrolizumab ve nivolumab gibi immünoterapi ajanları kullanılabilmektedir $(21,22)$.

Primer kutanöz lenfomalar (KL), tanı anında deri dışında tutulum olmaksızın deride bulunan lenfomalar olarak tanımlanır ve ekstranodal lenfomaların ikinci en yaygın şeklidir (23). Tüm primer KL'ın \%75-80'ini kutanöz $T$ hücreli lenfomalar (KTHL), \%20-25'ini primer kutanöz B hücreli lenfomalar (KBHL) oluşturur (24). Mikozis fungoides (MF), daha çok güneş görmeyen alanlarda ortaya çıkan yama, plak ve tümörlerle seyreden derinin en sık görülen primer kutanöz $T$ hücreli lenfomasıdır. İnsidansı 1 milyonda yaklaşık 4'tür (25). Erkek kadın oranı 2:1'dir (26). Mikozis fungoides, yama evresinde genellikle asemptomatik, bazen kaşıntılı olabilen ince skuamlı ve sıklıkla hafif atrofik eritematöz yamalar ile karakterizedir. Plak evresinde, daha belirgin, kalıcı, polimorfik, eritematöz plaklar izlenir. Plakların kalınlığı prognoz ile ilişkili bulunmuştur. Tümör evresinde ise lenf nodu tutulumu ve sistemik yayılım riski daha fazla olup prognoz daha kötüdür $(27,28)$. Kutanöz $B$ hücreli lenfomalar; Primer kutanöz mantle zon lenfoma (PKMZL), Primer kutanöz folikül merkez hücreli lenfoma (PKFMHL), Primer kutanöz diffüz büyük $B$ hücreli lenfoma, bacak tipi (PKDBBHL), EBV pozitif mukokutanöz ülser ve İntravasküler büyük B hücreli lenfoma olarak sınıflandırııı $(24,29)$.

Yumuşak doku sarkomları nadir görülen heterojen bir tümör grubunu oluşturmaktadır. Yaklaşık 50 farklı histopatolojik alt tipten oluşmaktadır. Avrupa'da insidansının 100.000'de 5 olduğu tahmin edilmektedir (30). Çok fazla alt grup içermesi nedeniyle burada çalışmamızdaki hastaların da çoğunluğunu oluşturan dermatofibrosarkoma protuberans (DFSP) ve Kaposi sarkomundan (KP) bahsedilecektir.

Dermatofibrosarkoma protuberans nadir görülen fibrohistiositik bir tümördür. Genellikle genç yetişkin kişilerin gövdesinde yerleşen yavaş büyüme gösteren palpasyonla fikse, viyolase plak veya nodül şeklinde ortaya çıkmaktadır $(31,32)$. Kadın ve erkekte görülme sıklığı eşittir (33). Tüm malignitelerin \%0,1'ini, yumuşak doku sarkomlarının yaklaşık \%1'lik kısmını oluşturan DFSP'nin yıllık insidansı milyonda 0,8-5 arasında değişmektedir $(32,33)$. Dermatofibrosarkoma protuberans yerleşim yeri, sıklığına göre gövde (\%42-60), üst ekstremite (\%23-25), alt ekstremite (\%18) ve baş-boyun (\%10-16) olarak sıralanmaktadır (32,33). Histopatolojik incelemede bal peteği görünümü oluşturan storiform paternde monomorfik iğsi hücreler görülür (33). Lokal invaziv bir tümör olan DFSP'un metastaz riski düşüktür $(\% 1,1)$ fakat fibrosarkomatöz transformasyon gösteren histolojik alt tipinde metastaz oranı \%14,5'a kadar çıkabilmektedir. Mortalite artışı ile ilişkili risk faktörleri; ileri yaş, tümör büyüklüğü, erkek cinsiyet, siyah ırk ve gövde yerleşimine kıyasla baş ve ekstremite yerleşimli olmasıdır. Tümörün lokal invaziv olması ve sık rekürrens gösterme özellikleri nedeniyle tedavide sınırların değerlendirilerek yapılan cerrahi yöntemlerin uygulanması önem taşımaktadır. Cerrahi uygulanamayan veya cerrahi sınır pozitiliği olup re-eksizyon uygulanamayan hastalarda radyoterapi uygulanabilir. İlerlemiş hastalıkta sistemik tedavi olarak imatib kullanılabilir (32).

Kaposi sarkomu, Kaposi sarkom ilişkili insan herpes virüsü-8 (HHV-8) tarafından meydana getirilen deride kırmızı kahverengi yama, plak ve nodüllerle ortaya çıkan anjiyoproliferatif bir tümördür. Klasik, endemik (Afrika), immünsupresif ilaç kullanımına bağlı iyatrojenik ve epidemik (AIDS ilişkili) olmak üzere 4 tipi mevcuttur. Deri dışında oral mukoza, gastrointestinal sistem, lenf nodu, akciğer ve karaciğer tutulumu yapabilir. Klasik tipi genellikle 6. dekadda ve erkeklerde daha sık görülür. Tedavi seçeneği hastalığın yaygınlığına ve iç organ tutuluma bağlı olarak değişmektedir. Deriye yönelik tedaviler arasında eksizyon, kriyoterapi, lazer uygulamaları, RT, topikal imikimod, timolol, rapamisin, intalezyonel vinblastin, doksorubisin, bleomisin, interferon alfa, sodyum teradesil sülfat bulunmaktadır. AIDS'li KS olgularında kombine antiretroviral 
tedavi ana tedaviyi oluşturur. İleri vakalarda antrasiklinler, paklitaksel, gemsitabin, vinkristin, etopozid ve bleomisin tek başına veya kombine olarak kullanılabilir $(34,35)$.

\section{Gereç ve Yöntem}

Bu çalışmada Ege Üniversitesi (EÜ) Hastanesi veri tabanındaki 1992-2017 yılları arası MDDK tanısı alan hastaların epidemiyolojik özellikleri değerlendirilmiştir. EÜ Kanserle Savaş Araştırma ve Uygulama Merkezinin (EÜKAM) özel eğitimli ve sertifikalı kanser kayıt elemanları tarafından kaydedilen 1992-2017 yılları arasında, Ege Üniversitesinde kayıtlı 8395 MDDK tanılı hastanın; tanı yaşı, cinsiyeti, tümörün histopatolojik tanısı, tümör yerleşimi, hastalık evresi ve uygulanan tedavi yöntemleri değerlendirilmiştir. Mevcut verilerde hastaların ölüm nedenleri olmadığından tümörlere ait sağ kalım (SK) oranları hesaplanamamıştır. Türkiye Cumhuriyeti kimlik numarası mevcut olan hastalarda genel SK (GSK) oranları belirtilecektir.

Çalışma için EÜ Tıbbi Araştırmalar Etik Kurulundan 20-4.2T/3 numarası ile onay alındı. CANREG 4 programı ile kaydedilen, SPSS 18.0 versiyonuna aktarılan retrospektif veriler ile hasta ve hastalık özelliklerinin sıklığı ve bu özelliklerin tümör yerleşim sıklığı açısından karşılaştırmaları araştırıldı. Verilerin tanımlayıcı istatistikleri; ortalama, standart sapma (medyan, minimum, maksimum) frekans ve yüzde değerleri olarak verildi. Kategorik değişkenler arası ilişki varlığı KiKare yöntemiyle değerlendirilirken, gruplar arası nümerik değişkenler Kruskal Wallis ve Dunn Testi ile karşılaştıııldı. İstatistiksel analizler IBM Corp. Released 2017. IBM SPSS Statistics for Windows, Version 25.0. Armonk, NY: IBM Corp. Paket programında gerçekleştirildi. Tüm Hipotez testleri 0,05 önem seviyesinde uygulandı.

\section{Bulgular}

Ege Üniversitesi Kanser Araştırma Merkezinde 1992 ile 2017 yılları arasında kayıtlı MDDK olan 8395 hastanın 8386'sı dahil edildi. Hastaların $\% 57,3$ 'ü erkek, \%42,7'si kadındı. Yaş ortalaması $63,3 \pm 14,3(0-102)$ idi. Hastaların tanıları SHK, BHK, BSK, deri eki tümörleri, MHK, lenfomalar, yumuşak doku tümörleri ve sınıflandırılamayan olarak ana alt başlıklara ayrıldı. Ana tanılar ve dağılımları (Tablo-1)'de gösterilmiştir. Yerleşim yerleri bilinen lezyonların \%7,1'i gövdede, \%4,6'sı alt ekstremitede, \%4'ü üst ekstremitede ve $\% 84,3$ 'ü baş ve boyunda yerleşmekteydi.

Tablo-1. Hasta grubundaki tanıların dağılımı (SHK: skuamoz hücreli karsinom, BHK: bazal hücreli karsinom, BSK: bazoskuamoz karsinom, MF: mikozis fungoides).

\begin{tabular}{|c|c|c|c|}
\hline \multicolumn{2}{|l|}{ Tanı } & $\begin{array}{l}\text { Sayı } \\
\text { (n) }\end{array}$ & \multirow{2}{*}{$\begin{array}{l}\text { Yüzde } \\
\% \\
89,6\end{array}$} \\
\hline \multirow{4}{*}{ 1.Epitelyal karsinom } & Alt tip & 7517 & \\
\hline & SHK & 2547 & 30,3 \\
\hline & $\mathrm{BHK}$ & 4686 & 55,9 \\
\hline & BSK & 284 & 3,4 \\
\hline \multirow{4}{*}{ 2. Deri eki kanserleri } & Alt tip & 117 & \multirow[t]{4}{*}{1,4} \\
\hline & Sebase diferansiyasyon & 20 & \\
\hline & Ekrin/apokrin diferansiyasyon & 85 & \\
\hline & Folliküler diferansiyasyon & 12 & \\
\hline \multicolumn{2}{|c|}{ 3. Merkel hücreli karsinom } & 33 & 0,4 \\
\hline \multirow{3}{*}{ 4. Lenfomalar } & Alt tip & 229 & \multirow{3}{*}{2,7} \\
\hline & $\begin{array}{l}\text { T lenfoma } \\
\bullet \quad M F \\
\bullet \quad M F \text { dışı } \\
\text { B lenfoma }\end{array}$ & 152 & \\
\hline & Diğer & 21 & \\
\hline \multicolumn{2}{|c|}{ 5. Malign yumuşak doku tümörleri } & 299 & 3,6 \\
\hline \multicolumn{2}{|l|}{ 6. Sınıflandırılamayan } & 191 & 2,3 \\
\hline
\end{tabular}




\section{Skuamöz Hücreli Karsinom}

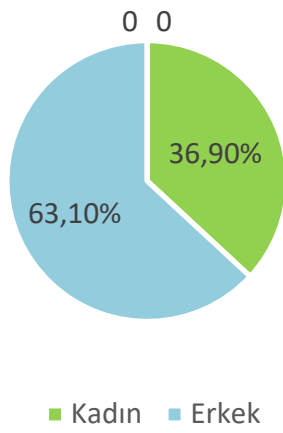

Şekil-1. SHK tanılı hastaların cinsiyet dağıımı (SHK: Skuamoz hücreli karsinom).

Tablo-2. SHK'nın histopatolojik alt tipleri ve görülme sıklığı (SHK: Skuamoz hücreli karsinom).

\begin{tabular}{lll}
\hline SHK'un histopatolojik alt tipi & $\begin{array}{l}\text { Sayı } \\
\text { (n) }\end{array}$ & $\begin{array}{l}\text { Yüzde } \\
\text { (\%) }\end{array}$ \\
\hline 1. Bowen hastalığı (SHK in situ) & 436 & 17,1 \\
2. SHK, BBT & 2000 & 78,5 \\
3. Mikroinvaziv SHK & 54 & 2,1 \\
4. Verrüköz karsinom & 30 & 1,2 \\
5. İ̆si hücreli SHK & 9 & \\
6. Adenoid SHK & 5 & \\
7. Psödosarkomatoz karsinom & 4 & \\
9. Adenoskuamoz karsinom & 3 & \\
10. Bazoloid SHK & 3 & \\
11. Nonkeratinize SHK & 2 & \\
12. Saydam hücreli tür SHK & 1 & \\
\hline
\end{tabular}

\section{kuamoz hücreli karsinom}

Verileri tam olan 2547 hastanın \%63,1'i erkek, $\% 36,9$ 'u kadındı (p:0,000) (Şekil-1). Yaş ortalaması $65,53 \pm 14,36$ idi $(0-100)$. Histolojik alt tiplerine göre dağılım (Tablo-2)'de gösterilmiş ve (Şekil-2)'de şematize edilmiştir. Lezyonun yerleşim yeri bilinen 2425 hastada yerleşim yeri sıklık sıralaması şu şekildeydi; yüzün spesifiye edilmemiş bölgeleri $(\% 36,3)$, dudak derisi $(\% 19,7)$, dış kulak $(\% 9)$, saçlı deri ve boyun $(\% 7,9)$, göz kapağı $(\% 6,5)$, üst ekstremite ve omuz $(\% 6)$, alt ekstremite ve kalça $(\% 5,1)$ ve gövde derisi (\%4,7) (p:0,000). Diferansiyasyon durumu belirtilen 989 lezyonun \%45,8'i iyi diferansiye, $\% 14,6$ 'sı orta derecede diferansiye, \%15'i az (kötü) diferansiye, \%1,7'si indiferansiye idi. T evresi bilinen 1399 hastanın \%27,9'u in situ, $\% 66,1$ 'i lokal, \%6'sı ise ileri evrede idi. Lenf nodu tutulum durumu 969 hastada bilinmekteydi. Bu hastaların \%7,4'ünde lenf nodu metastazı mevcuttu. Uzak metastaz olup olmadığı belirtilen 1020 olgunun \%2,3'ünde metastaz vardı. Tedavi bilgisi olan 2485 olgunun \%83,8'ine bir tedavi uygulanmıştı. Tedavi bilgisi verilen hastaların \%68'ine cerrahi, \%21,1'ine radyoterapi, \%1,8'ine kemoterapi, \%1,6'sına kriyoterapi uygulanmıştı.

\section{Skuamöz Hücreli Karsinom}

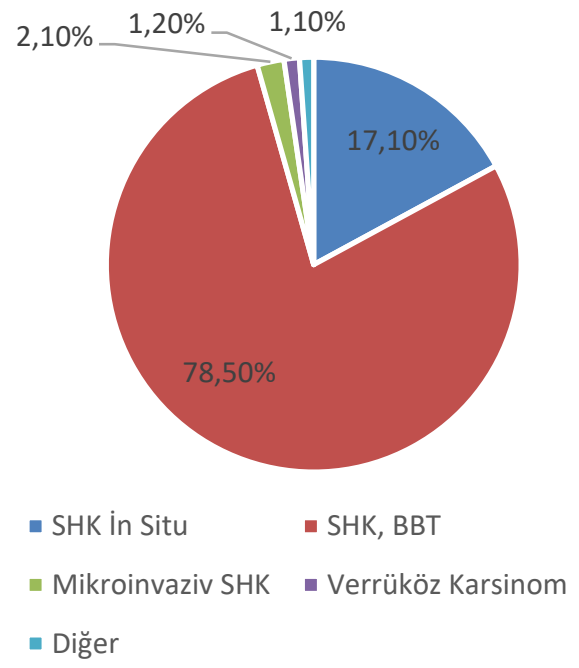

Şekil-2. SHK'un histopatolojik alt tiplerinin sıklığı (SHK: skuamoz hücreli karsinom).

\section{Bazal hücreli karsinom}

Ege Üniversitesi Kanser Araştırma Merkezinde 1992 ile 2017 yılları arasında kayıtlı 4686 BHK tanılı olgunun \%53,2'si erkek, \%46,8'i kadındı (p:0,000) (Şekil-3). Yaş ortalaması 63,2 $\pm 13,2$ (7102) idi. Verileri mevcut olan 4686 BHK tanılı hastanın histolojik alt tiplerine dağılımı (Tablo3)'de gösterilmiştir. Yerleşim yeri belirtilmiş olan 4367 hastada BHK lezyonu, \%58 yüzün belirtilmemiş bölgesinde, \%15,3 göz kapağında, $\% 8,1$ saçlı deri ve boyunda, $\% 7$ gövdede, $\% 6,3$ dış kulakta, \%3 dudak derisinde, \%1,6 üst ekstremite ve omuzda, \%0,8 alt ekstremite ve kalçada yerleşmişti. 


\section{Bazal Hücreli Karsinom}

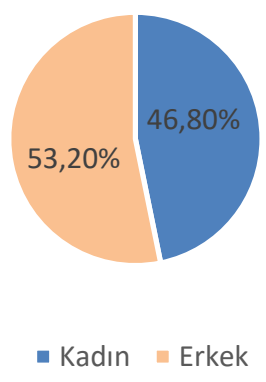

Şekil-3. BHK tanılı hastaların cinsiyet dağılımı (BHK: Bazal hücreli karsinom).

Tablo-3. BHK'nın histopatolojik alt tipleri ve görülme sıklığı (BHK: Bazal hücreli karsinom).

\begin{tabular}{lll}
\hline $\begin{array}{l}\text { BHK'un histopatolojik alt } \\
\text { tipi }\end{array}$ & $\begin{array}{l}\text { Sayı } \\
\text { (n) }\end{array}$ & $\begin{array}{l}\text { Yüzde } \\
\text { (\%) }\end{array}$ \\
\hline 1. BHK, BBT & 2534 & 54,1 \\
2. Nodüler BHK & 1546 & 33 \\
3. İnflitratif BHK, BBT & 329 & 7 \\
4. Süperfisyel Multifokal BHK & 245 & 5,2 \\
5. Metatipik karsinom & 18 & 0,4 \\
6. Fibroepitelyal tür BHK & 8 & 0,2 \\
7. Adenoid BHK & 6 & 0,1 \\
\hline
\end{tabular}

T evresi ile ilgili bilgi $2359(\% 50,3)$ hastada mevcuttu. T evresi bilgisi olan olguların dağılımı şu şekildeydi; \%98,2 lokal, \%1,8 ileri. Olguların 1663'ünün $(\% 35,5)$ lenf bezi tutulumu ile ilgili bilgi mevcuttu. Tutulum bilgisi mevcut olan hastaların $\% 0,5$ 'inde lenf bezi tutulumu vardı. Metastaz durumu ile bilgisi olan $1766(\% 37,7)$ hastanın $\% 0,2$ 'sinde metastaz vardı.

Tedavi uygulanma bilgisi olan 4589 hastanın $\% 84,6$ 'sına tedavi uygulanmışken \%15,4'üne herhangi bir tedavi uygulanmamıştı.

Tedavi bilgisi olan 4592 hastanın \%61,3'ne cerrahi tedavi uygulandı, \%38,7'sine uygulanmadı. Radyoterapi uygulanma bilgisi verilen 4585 hastanın \%22,4'üne RT uygulandı, $\% 77,6$ 'sına RT uygulanmadı. Kemoterapi uygulanma bilgisi verilen 4591 hastanın \%0,5'ine KT uygulanmıştı. Hastaların \%1,9'una kriyoterapi uygulanmıştı.

\section{Bazoskuamoz karsinom}

Dağılım ve ortalamalar EGEKAM'da 1992 ile 2017 yılları arasında kayıtlı 284 hasta üzerinden hesaplandı. Hastaların \%56'sı erkek, \%44'ü kadındı. Hastaların yaş ortalaması $65,73 \pm 12,34$ (19-95) idi. Lezyon yerleşim yerleri belirtilen 257 hastanın sıklığına göre şöyle sıralanmaktaydı; yüzün spesifiye olmamış bölgeleri $(\% 54,2)$, göz kapağı $(\% 9,9)$, saçlı deri ve boyun $(\% 8,5)$, dış kulak $(\% 8,5)$, dudak derisi $(\% 4,2)$, gövde $(\% 3,2)$, alt ekstremite ve kalça $(\% 1,4)$ ve üst ekstremite ve omuz $(\% 0,7)$. Hastaların $T$ evresi ile bilgileri 104 hastada mevcuttu. Bunların \%94,2'sinde tümör lokal iken \%5,8'inde ileriydi. Lenf bezi tutulum durumu bildirilen 66 hastanın birinde $(\% 1,5)$ lenf bezi tutulumu saptandı. Metastaz durumu bildirilen 77 hastanın birinde $(\% 1,3)$ hastada metastaz saptandı. Tedavi bilgisi 278 hastada mevcuttu. Hastaların \%74,5'una tedavi yapılmışken, \%25,5'ine tedavi yapılmamıştı. Uygulanan tedaviler; cerrahi (\%43,2), RT $(\% 32,1)$, kriyoterapi $(\% 3,5)$ ve kemoterapi $(\% 0,4)$ idi.

\section{Deri eki kanserleri}

Ege Üniversitesi Kanser Araştırma Merkezinde 1992 ile 2017 yılları arasında kayıtlı 121 deri eki kanseri olan olgunun \%57'si erkek, \%43'ü

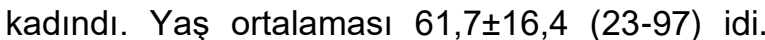
Verileri mevcut olan hastaların histolojik alt tiplerine yüzdeleri göre sıralaması (Tablo-4)'de gösterilmiştir. Yerleşim yeri belirtilen 112 hastada yerleşim yeri sıklığına göre sıralama şu şekildeydi; \%25,9 yüzün spesifiye edilmemiş bölgesi, \%16,1 gövde derisi, \%15,2 göz kapağı, $\% 13,3$ saçlı deri ve boyun, \%11,6 alt ekstremite ve kalça, $\% 8$ üst ekstremite ve omuz, $\% 5,4$ dış kulak ve $\% 4,4$ dudak derisi. Lenf nodu tutulum durumu belirtilen 41 hastanın \%24,4'ünde (n: 10) lenf nodu tutulumu mevcuttu. Metastaz durumu bilgisi olan 50 hastanın \%8'inde (n: 4) metastaz mevcuttu. Tedavi durumu bilgisi verilen hastaların \%93,7'sine tedavi yapılmıştı. \%84,9'una cerrahi tedavi, \%20,4'üne RT yapılmıştı. 
Tablo-4. Malign deri eki tümörlerinin histopatolojik alt tipleri ve görülme sıklığı.

\begin{tabular}{llcc}
\hline Malign deri eki tümörlerinin histopatolojik alt tipleri & Sayı (n) & Yüzde (\%) \\
\hline Sebase diferansiyasyon & Sebase adenokarsinom & 20 & 16,5 \\
& Ter bezi adenokarsinomu + & 22 & 18,2 \\
& Adenokarsinom, BBT & 25 & 20,7 \\
& Malign ekrin poroma & 11 & 9,1 \\
& Malign nodüler hidradenom & 2 & 1,7 \\
Ekrin/apokrin diferansiyasyon & Adenoid kistik karsinom & 9 & 7,4 \\
& Malign mikst tümör, BBT & 4 & 3,3 \\
& Skleroze ter bezi duktus karsinomu & 2 & 1,7 \\
& Ekrin papiller adenokarsinom & 2 & 1,7 \\
& Apokrin adenokarsinom & 9 & 7,4 \\
Foliküler diferansiasyon & Trikolemmal karsinom & 3 & 2,5 \\
Deri ekleri karsinomu, BBT & Pilomatriks karsinom & 4 & 3,3 \\
\hline
\end{tabular}

Tablo-5. Kutanöz lenfoma tipleri ve görülme sıklığı (MF: Mikozis fungoides, NK: Doğal öldürücü (Natural Killer).

\begin{tabular}{|c|c|c|c|c|}
\hline \multicolumn{3}{|c|}{ Kutanöz lenfoma tipleri } & \multirow{2}{*}{$\begin{array}{l}\text { Sayı (n) } \\
104\end{array}$} & \multirow{2}{*}{$\begin{array}{r}\text { Yüzde (\%) } \\
45,4\end{array}$} \\
\hline \multirow{6}{*}{ T hücreli } & 1. MF & & & \\
\hline & \multirow{5}{*}{ 2. MF dışı } & Alt tip & 48 & \multirow{5}{*}{20,9} \\
\hline & & NK/T hücreli lenfoma, nazal ve nazal tür & 1 & \\
\hline & & $\begin{array}{l}\text { Kutanöz T hücreli lenfoma, BBT + Matür T } \\
\text { hücreli lenfoma, BBT }\end{array}$ & 23 & \\
\hline & & $\begin{array}{l}\text { Anaplastik büyük hücreli lenfoma,T hücreli ve } \\
\text { "Null" hüc. Tür }\end{array}$ & \multirow[t]{2}{*}{5} & \\
\hline & & $\begin{array}{l}\text { Primer kutanöz CD30+ T hücreli lenfoproliferatif } \\
\text { hastalık }\end{array}$ & & \\
\hline \multirow{4}{*}{ B hücreli } & \multicolumn{2}{|l|}{ Alt tip } & 56 & \multirow[t]{4}{*}{24,5} \\
\hline & \multicolumn{2}{|c|}{$\begin{array}{l}\text { Malign lenfoma, büyük B hücreli, diffüz, BBT +ALK pozitif büyük B- } \\
\text { hücreli lenfoma }\end{array}$} & 35 & \\
\hline & \multicolumn{2}{|c|}{$\begin{array}{l}\text { Folliküler lenfoma, derece } 3 \text { + Folliküler lenfoma, derece } 2+ \\
\text { Folliküler lenfoma, BBT + Primer kutanöz folikül merkez hücreli } \\
\text { lenfoma }\end{array}$} & 14 & \\
\hline & \multicolumn{2}{|c|}{ Marginal zone B hücreli lenfoma, BBT } & 7 & \\
\hline \multirow{7}{*}{ Diğerleri } & \multicolumn{2}{|l|}{ Alt tip } & 21 & \multirow[t]{7}{*}{9,2} \\
\hline & \multicolumn{2}{|c|}{ Non-Hodgkin malign lenfoma, BBT } & 12 & \\
\hline & \multicolumn{2}{|c|}{ Malign lenfoma, BBT } & 4 & \\
\hline & \multicolumn{2}{|c|}{ Prekürsör hücreli lenfoblastik lenfoma, BBT } & 1 & \\
\hline & \multicolumn{2}{|c|}{ Hodgkin lenfoma, lenfositten zengin } & \multirow[t]{2}{*}{1} & \\
\hline & \multirow{2}{*}{\multicolumn{2}{|c|}{$\begin{array}{l}\text { Miyeloid sarkom } \\
\text { Plazmasitom, BBT }\end{array}$}} & & \\
\hline & & & 1 & \\
\hline
\end{tabular}


Tablo-6. Malign yumuşak doku tümörlerinin tipleri ve görülme sıklığı.

\begin{tabular}{lll}
\hline Malign yumuşak doku tümörlerinin histopatolojik alt tipleri & $\begin{array}{l}\text { Sayı } \\
\text { (n) }\end{array}$ & $\begin{array}{l}\text { Yüzde } \\
\text { (\%) }\end{array}$ \\
\hline Kaposi sarkomu & 175 & 58,5 \\
Dermatofibrosarkom, BBT (95) + Pigmentli dermatofibrosarkom protuberans (5) & 100 & 33,4 \\
Malign fibröz histiyositom & 5 & 1,7 \\
Langerhans hücreli histiyositozis, BBT & 6 & 2 \\
Leiomyosarkom, BBT & 3 & 1 \\
Liposarkom & 3 & 1 \\
Histiyositik sarkom & 3 & 1 \\
Anjiyosarkom & 2 & 0,7 \\
Fibrosarkom, BBT & 2 & 0,7 \\
\hline
\end{tabular}

\section{Merkel hücreli karsinom}

Ege Üniversitesi Kanser Araştırma Merkezinde 1992 ile 2017 yılları arasında kayıtı 33 MHK olan olgunun \%57,6'sı kadın, \%42,4'ü erkekti. Yaş ortalaması $62,7 \pm 16,1$, medyan yaş 64 (26-88) idi. Yerleşim yeri belirtilen 29 hastada yerleşim yeri sıklığına göre sıralama şu şekildeydi; \%37,9 alt ekstremite ve kalça, \%17,2 yüzün spesifiye edilmemiş bölgesi, \%17,2 gövde derisi, \%10,3 üst ekstremite ve omuz, $\% 6,9$ saçlı deri ve boyun, \%6,9 göz kapağı ve \%3,4 dudak derisi. Lenf bezi tutulum durumu belirtilen 17 hastanın $\% 47$ 'sinde ( $\mathrm{n}$ : 8 ) lenf bezi tutulumu mevcuttu. Metastaz durumu bilgisi olan 14 hastanın \%21,4'ünde (n: 3) metastaz mevcuttu. Tedavi durumu bilgisi verilen hastaların \%93,7'sine tedavi yapılmıştı. \%75'ine cerrahi tedavi, \%25,8'ine RT, \%22,6'sına kemoterapi yapılmıştı.

\section{Kutanöz Lenfomalar}

Ege Üniversitesi Kanser Araştırma Merkezinde 1992 ile 2017 yılları arasında kayıtlı 229 kutanöz lenfoma tanılı olgunun \%54,6'sı erkek, \%45,4'ü kadındı. Yaş ortalaması 52,2 $\pm 17,4(0-99)$ idi. Hastaların lenfoma tiplerine göre dağılımı (Tablo5)'de gösterilmiştir. Lezyonun yerleşim yeri belirtilen 140 hastanın yerleşim yeri sıklığına göre sıralaması şu şekildeydi, \%33,6 gövde, \%17,9 yüzün spesifiye edilmemiş bölgesi, \%17 üst ekstremite ve omuz, \%15 alt ekstremite ve kalça, $\% 10,7$ saçlı deri ve boyun, \%2,8 göz kapağı, $\% 2,1$ dudak, \%0,7 dış kulak. Hastaların $\% 66,4$ 'ünde $\mathrm{T}$ hücre $\% 24,9$ 'unda ise $\mathrm{B}$ hücre diferansiyasyonu mevcuttu; \%8,7'sinde ise diferansiyasyon belirtilmemişti. Hastaların \%9,3'üne cerrahi, \%16,8'ine RT, \%23,7'sine kemoterapi, \%2,8'ine immünoterapi ve \%22,7'sine psoralen ve Ultraviyole-A (PUVA) tedavisi uygulanmıştı.

\section{Malign yumuşak doku tümörleri}

Ege Üniversitesi Kanser Araştırma Merkezinde 1992 ile 2017 yılları arasında kayıtı 299 malign yumuşak doku kanseri olan olgunun \%69,6'sı erkek, \%30,4'ü kadındı. Yaş ortalaması $55,5 \pm 20,8 \quad(0-97)$ idi. Verileri mevcut olan hastaların histolojik alt tiplerinin dağılımı (Tablo6)'da gösterilmiştir. Yerleşim yeri belirtilen 253 hastada yerleşim yeri sıklığına göre sıralama şu şekildeydi; \%46,2 alt ekstremite ve kalça, \%15,7 üst ekstremite ve omuz, $\% 15,4$ gövde, yüzün spesifiye edilmemiş bölgesi, \%16,1 gövde derisi, \%15,2 göz kapağı, \%13,3 saçlı deri ve boyun, $\% 11,6$ alt ekstremite ve kalça, $\% 8$ üst ekstremite ve omuz, $\% 5,4$ dış kulak ve $\% 4,4$ dudak derisi. Lenf bezi tutulum durumu belirtilen 76 hastanın \%11,8'inde (n: 9) lenf bezi tutulumu mevcuttu. Metastaz durumu bilgisi olan 107 hastanın $\% 4,7$ 'sinde ( $\mathrm{n}$ : 5) metastaz mevcuttu. Tedavi durumu bilgisi verilen hastaların \%79,6'sına tedavi uygulanmış olup $\% 58,2$ 'sine cerrahi tedavi, $\% 18,3$ 'üne RT, \%17,5'ine kemoterapi yapılmıştı.

Türkiye Cumhuriyeti kimlik numarası mevcut olan hastalarda GSK aşağıda belirtildiği gibidir. Tüm grubu içeren hastalardaki 5 yıllık GSK oranı $\% 82,8$ olarak saptandı. Alt gruplar değerlendirildiğinde SHK için 5 yıllık GSK oranı tüm hastalarda $\% 73$, erkeklerde $\% 72$, kadınlarda $\% 74$ idi. Bazal hücreli karsinomda 5 yıllık GSK oranı tüm hastalarda $\% 88,1$, erkeklerde $\% 87,2$, kadınlarda \%89,2 idi. Bazoskuamoz hücreli karsinomda 5 yıllık GSK \%80, kadınlarda \%76, 
erkeklerde \%83'tü. Malign deri eki kanserlerinde 5 yıllık GSK oranı tüm hastalarda $\% 75$, erkeklerde \%70,7, kadınlarda \%81,5 idi. Merkel Hücreli karsinomda 5 yıllık GSK oranı tüm hastalarda \%62,5'di. Kutanöz lenfomalarda 5 yıllık GSK oranı tüm hastalarda $\% 82,5$, erkeklerde $\% 85$, kadınlarda ise $\% 81$ idi. Malign yumuşak doku tümörlerinde 5 yıllık GSK oranı tüm hastalarda $\% 85,7$, erkeklerde $\% 81$, kadınlarda \%93,7 idi. Dermatofibrosarkomda 5 yıllık GSK \%94,8, kaposi sarkomunda ise $\% 79,5$ idi.

\section{Tartışma}

Bu çalışmada 1992-2017 yılları arasındaki 25 yıllık dönemde Ege Üniversitesi Kanser Araştırma Merkezinde kayıtlı olan MDDK epidemiyolojik açıdan değerlendirildi. Literatüre benzer şekilde vakaların çoğunluğunu epitelyal karsinomlar oluşturmaktaydı. Çalışmada en sık görülen MDDK tipi sıklık sırası ile BHK ve SHK idi. Bu çalışmada en az görülen MDDK, MHK'du. Merkel hücreli karsinom dışında tüm MDDK'larda erkek cinsiyet daha baskındı. Yaş ortalaması en genç olan grup kutanöz lenfomalarken, en ileri yaş gruplu tümör SHK idi.

Hastanemizden Ceylan ve ark.ının 1990-1999 yılları arasında SHK ve BHK'dan oluşan 2879 MDDK hastasını retrospektif olarak değerlendirdiği çalışmada, BHK olguların $\% 73,4$ 'ünü, SHK ise \%26,6'sını oluşturmaktaydı. Çalışmalarında hastaların \%56,7'si erkek, yaş ortalaması ise $62,81 \pm 12,50$ idi (36). Bu çalışmada ise BHK ve SHK toplamının \%64,8'ini BHK oluşturmaktaydı. Aynı coğrafi bölge çalışması olması nedeniyle benzer olarak çalışmamızda hastaların $\% 57,3$ 'ünü erkek ve yaş ortalamasını $63,3 \pm 14,3$ olarak saptadık.

Kutanöz SHK en sık olarak \%55 oranında baş ve boyun bölgesinde, \%18 oranında el ve ön kolun ekstansör yüzeyinde, \%13 oranında bacaklarda yerleşmekle birlikte vücudun herhangi bir alanında görülebilir (4). Bu çalışmada kSHK $\% 76,4$ baş ve boyun, $\% 6$ üst ekstremite ve $\% 5,1$ oranında alt ekstremitede yerleşmişti. Lenf bezi metastazının tahmin edilen insidansı \%3,7-5 arasında değişmektedir (2). Metastatik SHK insidansı \%0,5-16 olarak bildirilmiştir (1). Bu çalışmada lenf bezi tutulumu \%7,4 ve metastaz oranı $\% 2,3$ olarak bulunmuştur.

Bazal hücreli karsinom içinde en sık görülen tip nodüler BHK (\%50-80) olup bunu süperfisyel multifokal BHK (\%15) izler. Daha az görülen tipler nodülokistik (\%5), mikronodüler (\%2-20), morfeiform (\%0,0004-10), infiltratif BHK, Pinkus'un fibroepitelyoması $(\% 0,2-1,4)$ olarak sayılabilir (37). Çalışmamızda histopatolojik alt tipin belirtildiği BHK'larda sıklık sıralaması şu şekildeydi; nodüler BHK, infiltratif BHK ve süperfisyel multifokal BHK. Literatürde olduğu gibi bu çalışmada da erkek cinsiyet üstünlüğü gözlendi. Bazal hücreli karsinom metastaz oranları \%0,003-0,55 olarak bildirilmektedir (1). $\mathrm{Bu}$ çalışmada metastaz oranı \%0,2 olarak saptandı.

Literatürde BSK'un lenf bezi metastaz oranı $\% 2$ ile 17,9 arasında uzak metastaz oranı $\% 2,2$ ile 8,6 arasında bildirilmiştir (38). Bu çalışmada lenf bezi metastaz oranı $\% 1,3$, uzak metastaz oranı $\% 1,3$ olarak saptandı.

Literatürde MHK için erkek cinsiyet sıklığı bildirilmekle birlikte, bu çalışmada kadın cinsiyet daha sık saptandı (20). Literatürde tanı sırasında ortanca yaş 75-80 olarak bildirilmiştir (22). Çalışmamızda ortanca tanı yaşı 64 'tü.

Tüm primer KL'ın \%75-80'ini kutanöz T hücreli lenfomalar (KTHL), \%20-25'ini primer kutanöz B hücreli lenfomalar (KBHL) oluşturur (24). Bu çalışmada da KTHL \%66,3, KBHL \%24,5 oranında saptandı. MF KTHL'ların \%60'ını ve tüm primer kutanöz lenfomaların \%39'unu oluşturur $(23,24)$. Bu çalışmada MF primer KL'nin \%45,4'ünü oluşturmaktaydı.

Malign yumuşak doku kanserlerinde hem sık görülmemesi hem de çok sayıda alt grubu barındırması nedeniyle epidemiyolojik çalışmaların yapılması güçtür. Dermatofibrosarkoma protuberansın orta yaşlı bireylerde görülmesi dışında diğer kutanöz yumuşak doku sarkomları genellikle ileri yaşlarda görülmektedir (39). Wollina ve ark.ının 67 primer kutanöz sarkomun değerlendirildiği retrospektif çalışmasında \%78,5 oranında erkek cinsiyet baskınlığı görülmüş ve yaş ortalaması $73,1 \pm 5,5$ olarak saptanmıştır (40). Bizim çalışmamızda da erkek cinsiyet baskınlığı \%69,6 oranındaydı ve yaş ortalaması $55,5 \pm 20,8$ idi. Wollina ve ark.nın çalışmasında ve çalışmamız arasında sarkom tipleri ve dağılımı açısından farklılar mevcuttur. Onların çalışmasında 43 lezyon atipik fibroksantom iken Kaposi sarkomu tanısı alan 3, DFSP tanısı alan 2 lezyon mevcuttu (40).

\section{Sonuç}

Sonuç olarak melanom dışı deri kanserleri, histopatolojik olarak farklı hücrelerden köken 
alabilen, farklı tümör tiplerinden oluşmaktadır. Bu grupta en sık görülen klinik tipler BHK ve SHK olup; etiyolojik faktörler açısından en önemli faktörün ultraviyole maruziyeti olduğu görülmektedir. MDDK'nin prognozunu; tümörün histopatolojik özellikleri, diferansiyasyon derecesi, tümör boyutu ve yerleşimi, metastaz varlığı, skar dokusu gibi öncü lezyonların varlığı, immunsupresyon durumu gibi özel faktörler belirlemektedir. Bu grupta epidemiyolojik ve demografik veriler daha net iken, nadir görülen diğer tümörlere ilişkin bilgi ve veriler değişkenlik göstermektedir.

Çıkar çatışması: Yazarlar çıkar çatışması beyan etmemişlerdir.

\section{Kaynaklar}

1. Apalla Z, Lallas A, Sotiriou E, Lazaridou E, loannides D. Epidemiological trends in skin cancer. Dermatol Pract Concept. 2017;7(2):1-6.

2. Motaparthi K, Kapil JP, Velazquez EF. Cutaneous Squamous Cell Carcinoma: Review of the Eighth Edition of the American Joint Committee on Cancer Staging Guidelines, Prognostic Factors, and Histopathologic Variants. Adv Anat Pathol. 2017;24(4):171-94.

3. Ünal İ, Acar A. Skuamoz Hücreli Karsinom.Özkan AŞ, Akyol M, Editör. Dermatoonkoloji. 1. Baskı. İzmir: O'xxTIP Kitabevi; 2019:78-92.

4. Kallini JR, Hamed N, Khachemoune A. Squamous cell carcinoma of the skin: epidemiology, classification, management, and novel trends. Int J Dermatol. 2015;54(2):130-40.

5. Parekh V, Seykora JT. Cutaneous Squamous Cell Carcinoma. Clin Lab Med. 2017;37(3):503-25.

6. Work Group; Invited Reviewers, Kim JYS, Kozlow JH, Mittal B, Moyer J, Olenecki T, Rodgers P. Guidelines of care for the management of cutaneous squamous cell carcinoma. J Am Acad Dermatol. 2018;78(3):560-578.

7. Tanese K. Diagnosis and Management of Basal Cell Carcinoma. Curr Treat Options Oncol. 2019;20(2):13.

8. Rubin AI, Chen EH, Ratner D. Basal-cell carcinoma. N Engl J Med. 2005;353(21):2262-9.

9. Miller DL, Weinstock MA. Nonmelanoma skin cancer in the United States: incidence. J Am Acad Dermatol. 1994; 30:774-8.

10. Zanetti R, Rosso S, Martinez C, Nieto A, Miranda A, Mercier M, et al. Comparison of risk patterns in carcinoma and melanoma of the skin in men: a multiCentre case-case-control study. Br $\mathrm{J} \mathrm{Cancer}$. 2006;94:743-51

11. Boonchai W, Green A, Ng J, Dicker A, Chenevix-Trench G. Basal cell carcinoma in chronic arsenicism occurring in Queensland, Australia, after ingestion of an asthma medication. J Am Acad Dermatol. 2000;43:664-9.

12. Watt TC, Inskip PD, Stratton K, Smith SA, Kry SF, Sigurdson AJ, et al. Radiation-related risk of basal cell carcinoma: a report from the childhood cancer survivor study. J Natl Cancer Inst. 2012;104:1240-50.

13. Silverberg MJ, Leyden W, Warton EM, Quesenberry CP Jr, Engels EA, Asgari MM. HIV infection status, immunodeficiency, and the incidence of non-melanoma skin cancer. J Natl Cancer Inst. 2013;105:350-60.

14. Walling HW, Fosko SW, Geraminejad PA, Whitaker DC, Arpey CJ. Aggressive basal cell carcinoma: presentation, pathogenesis, and management. Cancer Metastasis Rev 2004;23:389-402.

15. NCCN.org [homepage on the internet]. Pennsylvania: National Comprehensive Cancer Network. Basal cell skin cancer [Version 1.2020-October 24,2019]. Available from: https://www.nccn.org/professionals/physician_gls/pdf/nmsc.pdf.

16. Tan CZ, Rieger KE, Sarin KY. Basosquamous Carcinoma: Controversy, Advances, and Future Directions. Dermatol Surg. 2017;43(1):23-31.

17. Shukla S, Khachemoune A. Reappraising basosquamous carcinoma: a summary of histologic features, diagnosis, and treatment. Arch Dermatol Res. 2020 Mar 12.

18. Güler Şimşek G, Yalçın GŞ. Deri Eki Tümörlerin Dünya Sağlık Örgütü Sınıflandırması. Güncel Patoloji Dergisi. 2019; 3(1):15-20.

19. Craig PJ. An Overview of Uncommon Cutaneous Malignancies, Including Skin Appendageal (Adnexal) Tumours and Sarcomas. Clin Oncol (R Coll Radiol). 2019;31(11):769-78.

20. Harms PW. Update on Merkel Cell Carcinoma. Clin Lab Med. 2017;37(3):485-501.

21. Yazıcı S, Bülbül Başkan E. Merkel hücreli karsinom. Özkan AŞ, Akyol M, Editör. Dermatoonkoloji. 1. Baskı. İzmir: O’xxTIP Kitabevi; 2019:301-6.

22. Becker JC, Stang A, DeCaprio JA, et al. Merkel cell carcinoma. Nat Rev Dis Primers. 2017;3:17077. 
23. Willemze R, Cerroni L, Kempf W, et al. (2019) The 2018 update of the WHOEORTC classification for primary cutaneous lymphomas. Blood. blood-2018-11-881268

24. Elder DE, Massi D, Scolyer RA, Willemze R.WHO Classification of Skin Tumours. 4th ed. Lyon, France: IARC Press; 2018.

25. Foss, F. M., \& Girardi, M. (2017). Mycosis Fungoides and Sezary Syndrome. Hematology/Oncology Clinics of North America, 31(2), 297-315.

26. Morales Suárez-Varela, M. M., Llopis González, A., Marquina Vila, A., \& Bell, J. (2000). Mycosis fungoides: Review of Epidemiological Observations. Dermatology, 201(1), 21-8.

27. Whittaker S, Child F. Cutaneous Lymphomas. In: Griffiths C, Barker J, Bleiker T, Chalmers R, Creamer D (ed). Rook's Textbook of Dermatology. 9th ed. Oxford, UK: Wiley-Blackwell; 2016:140.1-140.50.

28. Talpur, R., Singh, L., Daulat, S., Liu, P., Seyfer, S., Trynosky, T., Duvic, M. (2012). Long-term Outcomes of 1,263 Patients with Mycosis Fungoides and Sezary Syndrome from 1982 to 2009. Clinical Cancer Research, 18(18), 5051-60.

29. Kempf, W., Zimmermann, A., \& Mitteldorf, C. (2019). Cutaneous lymphomas-An update 2019. Hematological Oncology, 37(S1), 43-7.

30. Garcia del Muro X, de Alava E, Artigas V, et al. Clinical practice guidelines for the diagnosis and treatment of patients with soft tissue sarcoma by the Spanish group for research in sarcomas (GEIS). Cancer Chemother Pharmacol. 2016;77(1):133-46.

31. Acar A, Karaarslan I, Ozturk G, Yaman B, Ozdemir F. Reflectance confocal microscopic findings in a case of huge dermatofibrosarcoma protuberans. Wien Med Wochenschr. 2020 Mar 13.

32. Acosta AE, Vélez CS. Dermatofibrosarcoma Protuberans. Curr Treat Options Oncol. 2017;18(9):56.

33. Allen A, Ahn C, Sangüeza OP. Dermatofibrosarcoma Protuberans. Dermatol Clin. 2019;37(4):483-88.

34. Etemad SA, Dewan AK. Kaposi Sarcoma Updates. Dermatol Clin. 2019;37(4):505-17.

35. Gündüz K. Vasküler Tümörler. Özkan AŞ, Akyol M, Editör. Dermatoonkoloji. 1. Baskı. İzmir: O’xxTIP Kitabevi; 2019:261-81.

36. Ceylan C, Ozturk G, Alper S. Non-melanoma skin cancers between the years of 1990 and 1999 in Izmir, Turkey: Demographic and clinicopathological characteristics. J Dermatol 2003;30 (2):123-131.

37. Özkan A.Ş., Bazal hücreli karsinom. Özkan AŞ, Akyol M, Editör. Dermatoonkoloji. 1. Baskı. İzmir: O’xxTIP Kitabevi; 2019:48-77.

38. Wermker K, Roknic N, Goessling K, Klein M, Schulze HJ, Hallermann C. Basosquamous carcinoma of the head and neck: clinical and histologic characteristics and their impact on disease progression. Neoplasia. 2015;17(3):301-5.

39. Kohlmeyer J, Steimle-Grauer SA, Hein R. Cutaneous sarcomas. J Dtsch Dermatol Ges. 2017;15(6):630-48.

40. Wollina U, Koch A, Hansel G, et al. A 10-year analysis of cutaneous mesenchymal tumors (sarcomas and related entities) in a skin cancer center. Int J Dermatol. 2013;52(10):1189-97. 